\title{
Attitudes of medical university students towards the functioning of homosexual men and women in public places
}

\section{Studenci uniwersytetu medycznego o funkcjonowaniu mężczyzn i kobiet homoseksualnych w przestrzeni publicznej}

\author{
Joanna Tkaczuk-Włach ${ }^{1, A-D \oplus}$, Lechosław Putowski ${ }^{1, F \oplus}{ }^{\oplus}$, Anna B. Pilewska-Kozak ${ }^{1, E \oplus ~}$ \\ ${ }^{1}$ The Faculty of Health Sciences, Medical University of Lublin, Poland \\ A - Research concept and design, B - Collection and/or assembly of data, C - Data analysis and interpretation, \\ $D$ - Writing the article, $E$ - Critical revision of the article, F - Final approval of article
}

Tkaczuk-Włach J, Putowski L, Pilewska-Kozak A. B. Attitudes of medical university students towards the functioning of homosexual men and women in public places. Med Og Nauk Zdr. 2020; 26(3): 291-294. doi: 10.26444/monz/120130

\begin{abstract}
Introduction and objective. Homosexual men and women are often perceived as a threat to traditional values, particularly to the family. The aim of this study is to investigate the attitude of medical university students to the functioning of homosexual men and women in society, and whether it is related to their standpoint towards homosexuality and the auto declaration of faith.

Materials and method. The research comprised 152 students of the Medical University in Lublin, in eastern Poland. The research method was a diagnostic survey using an original questionnaire. The data was analyzed descriptively and statistically. The non sequitur was $5 \%$ and the related significance level was $\mathrm{p}<0.05$.

Results. 119 (78.3\%) of respondents declared themselves as believers and the remaining 33 (21.7\%) described themselves as non-believers. Being a believer significantly differentiated the declared attitude to homosexuality $(p=0.005)$. Views on the four chosen social rights which could (or could not) be granted to homosexual people were divided. The variables assumed in this research significantly differentiated all the examined features $(p<0.05)$.

Conclusions. The majority of medical university students declared themselves to be indifferent or negative towards homosexuality. They opposed the legalization of rights which homosexual men and women strive for, including the right to adopt children and contract a same-sex marriage. The acceptance of some social rights for homosexual men and women is significantly differentiated by the attitude of students towards homosexuality and their auto declaration of faith.
\end{abstract}

\section{Key words}

homosexuality, sexual minorities, homosexual men and women in society, social rights

\section{Streszczenie}

Cel pracy. Homoseksualni mężczyźni i kobiety są często postrzegani jako zagrożenie dla tradycyjnych wartości, szczególnie dla rodziny. Celem pracy jest zbadanie opinii studentów uniwersytetu medycznego na temat funkcjonowania homoseksualnych mężczyzn i kobiet w społeczeństwie oraz tego, czy ma to związek z ich stanowiskiem wobec homoseksualizmu i deklaracją wiary.

Materiał i metody. Badaniem objęto 152 studentów Uniwersytetu Medycznego w Lublinie. Wykorzystano w nim metodę sondażu diagnostycznego, który przeprowadzono, korzystając z kwestionariusza ankiety własnej konstrukcji. Przyjęto 5\% błąd wnioskowania i związaną z nim istotność na poziomie $\mathrm{p}<0.05$.

Wyniki. 119 (78,3\%) respondentów zadeklarowało się jako osoby wierzące, a pozostałe 33 osoby $(21,7 \%)$ określiły się jako niewierzące. Bycie wierzącym znacznie różnicowało deklarowane podejście do homoseksualizmu $(p=0,005)$. Poglądy na temat czterech wybranych praw socjalnych, które można (lub których nie można) przyznać osobom homoseksualnym, były podzielone. Zmienne przyjęte $w$ tym badaniu istotnie różnicowały wszystkie badane cechy $(p<0,05)$.

Wnioski. Większość studentów uniwersytetu medycznego deklaruje obojętne lub negatywne podejście do homoseksualizmu. Sprzeciwiali się legalizacji praw, o które zabiegają homoseksualni mężczyźni i kobiety, w tym prawa do adopcji dzieci i zawierania małżeństw przez osoby tej samej płci. Akceptacja niektórych praw socjalnych dla homoseksualnych mężczyzn i kobiet jest znacznie zróżnicowana ze względu na stosunek studentów do homoseksualizmu i ich deklarację wiary.

\section{Słowa kluczowe}

homoseksualizm, mniejszości seksualne, homoseksualni mężczyźni i kobiety w społeczeństwie, prawa społeczne
Address for correspondence: Anna B. Pilewska-Kozak, Medical University, Poland E-mail: apilewska@poczta.wp.pl

Received: 09.01.2020; accepted: 06.04.2020; first online: 13.05.2020

\section{INTRODUCTION}

The existence of sexual minorities generates more or less intensified social problems in many countries [1-3]. In Poland, homosexual men and women are often seen as a source of threat to traditional values, particularly to the 
family [4]. Usually, homosexual men and women are not accepted in life and the workplace environment, which poses a threat to their health and psychic well-being [5-7].

Homosexual men and women have been fighting for their rights, which in the majority of civilized countries, are granted to heterosexual couples [8]. They organize protests against social discrimination, which even if supported by heterosexual people, often produce an opposite effect.

A reluctant attitude to LGBT persons is frequent in Poland: $84 \%$ of them are anxious for their own safety, $20.2 \%$ have faced physical assault, 54.6\% psychological violence and $23.5 \%$ feel they are derogated during contact with the health services [9].

The aim of this study was to investigate the attitude of medical university students towards the functioning of homosexual men and women in society, and whether it is related to their standpoint towards homosexuality and their auto declaration of faith.

\section{MATERIALS AND METHOD}

The study was conducted among 152 students of the Medical University in Lublin, eastern Poland: 38 (25\%) medical students, 34 (22.4\%) pharmacy students, 38 (25\%) rescue and physiotherapy students, and $42(27.6 \%)$ nursing and midwifery students. Acceptance by students to be a part of the studied group constituted the condition under which they could be participants. The study method was a diagnostic survey using an original questionnaire prepared specifically for the study. It included questions concerning the studied subject and personal data of the participant, i.e. age, gender and university faculty. In the questionnaire construction, the available literature was used, and the opinions of a group of experts (professors, doctors of medicine, psychology and sociology) were taken into account. A pilot study was conducted among 15 students to verify the accuracy and usefulness of the questions in the questionnaire. Eventually, the pilot research results were excluded from the main study.

The study respondents were students in all faculties of the Medical University in Lublin, eastern Poland, although the percentage of participation was approximately the same. The study was carried out in accordance with the principles of the Helsinki Declaration. Each of the respondents was informed about the aim of the research and how to complete the questionnaire, which carried out individually, without the presence of a pollster. All the respondents were assured the anonymity of the questionnaire results and their use for only for scientific purposes.

The material collected was analyzed descriptively and statistically. The values of the analyzed parameters measured on a nominal scale were characterized with the use of numerousness and percentage. The values measured in a quotient scale were described with the use of an arithmetic mean and the standard deviation. The homogeneity or $\chi^{2}$ independence test were used to evaluate the differences or correlations between analyzed non-measurable parameters. The Yates correction was applied for small numerousness (below 5). The non sequitur was 5\% and the related significance level was $\mathrm{p}<0.05$, which indicated the statistically significant differences or correlations [10]. Statistical analyses were based on the computer program STATISTICA v. 7.1 (StatSoft, Poland).

\section{RESULTS}

94 (61.8\%) women and 58 (38.2.\%) men participated in the research. Their ages ranged from 19-26, with an average of $22.6 \pm 3.7 .119(78.3 \%)$ of the respondents described themselves as believers and $33(21.7 \%)$ as non-believers. 23 (15.1\%) of the respondents declared a positive attitude towards homosexuality, 47 (30.9\%) were negative about the issue and $82(54.0 \%)$ remained indifferent. Statistical analysis showed that the fact of being a believer significantly differentiated the declared attitude of the respondents towards homosexuality $(\mathrm{p}=0.005)$.

The respondents' opinions concerning four chosen rights which could (or could not) be granted to homosexual men and women in society, were divided. 42 (27.6\%) of the respondents approved of the right to show one's own sexuality publicly, and 71 (46.7\%) refrained from expressing an opinion. In the case of the right to perform a chosen profession (without any constraints), the opinions were as follows: 61 (40.1\%), 73 (48.0\%) and 18 (11.9\%). According to the respondents, the 'forbidden' professions for homosexual men and women should include all professions connected with working with children ( $42 ; 57.5 \%$ of this group), and the medical professions, such as doctors, nurses and midwives (15; 20.5\%). Homosexual men and women should also not be permitted work as clerics $(14 ; 19.2 \%)$, as members of uniformed services, or in public administration (12; 7.9\%).

The right to contract a same-sex marriage was accepted by $39(25.6 \%)$ of the respondents, whereas 93 (61.2) of the surveyed students were against this right, and 20 (13.2\%) had no opinion whatsoever. As far as the right to adopt children is concerned, the answers were analogical: 16 (10.5\%), $122(80.3 \%)$ and 14 (9.2\%). The correlation between the presented standpoints of the respondents (concerning the above-mentioned rights for homosexual men and women and homosexual relationships) and their auto declaration of faith are shown in the Table 1.

The auto declaration of faith significantly differentiated in all of the analyzed rights $(\mathrm{p}<0.05)$. Definitely the most different standpoints between believers and non-believers concerned the right to perform a chosen profession and contract a marriage. More than a half of both these groups differed in their opinions on manifesting one's own sexuality, while believers did not express an opinion on the subject, and non-believers supported the right. In the case of the right to adopt children, the majority (84.4\%) of believers and more than a half $(54.6 \%)$ of non-believers were opposed to this right for homosexual couples. The correlation between the acceptance of social rights and the respondents attitude to homosexuality are presented in Table 2 .

The acceptance (or non-acceptance) of all the analyzed social rights was significantly differentiated by the declared attitude of the respondents to homosexuality $(\mathrm{p}<0.05)$.

The opinions of the respondents on how homosexual men and women who openly admitted their sexual orientation should be treated in a workplace were divided. The opinions that they should be treated like other employees $(58 ; 38.2 \%)$ occurred equally often regarding the standpoint that homosexual men and women should encounter worse treatment $(58 ; 38.2 \%)$. The rest of the respondents did not know what to answer $(34 ; 22.4 \%)$, and few said that homosexual orientation would positively influence the way of treatment in the workplace $(2 ; 1.3 \%)$. It is worth mentioning 
Table 1. The attitude to the chosen social rights and the auto declaration of faith

\begin{tabular}{|c|c|c|c|c|c|}
\hline \multirow{3}{*}{ Examined features } & \multicolumn{4}{|c|}{ Respondents } & \multirow{3}{*}{ Significance } \\
\hline & \multicolumn{2}{|c|}{$\begin{array}{c}\text { Believers } \\
\mathrm{n}=119 ; 78.3 \%\end{array}$} & \multicolumn{2}{|c|}{$\begin{array}{c}\text { Non-believers } \\
n=33 ; 21.7 \%\end{array}$} & \\
\hline & $\mathrm{n}$ & $\%$ & $\mathrm{n}$ & $\%$ & \\
\hline \multicolumn{6}{|c|}{ The right to manifest one's own sexuality } \\
\hline $\begin{array}{l}\text { Yes } \\
n=42 ; 27.6 \%\end{array}$ & 25 & 21.0 & 17 & 51.5 & \multirow{3}{*}{$\begin{array}{c}x^{2}=12.496 \\
p=0.002\end{array}$} \\
\hline $\begin{array}{l}\text { No } \\
n=39 ; 25.7 \%\end{array}$ & 32 & 26.9 & 7 & 21.2 & \\
\hline $\begin{array}{l}\text { Don't know } \\
n=71 ; 46.7 \%\end{array}$ & 62 & 52.1 & 9 & 27.3 & \\
\hline \multicolumn{6}{|c|}{ The right to perform a chosen profession without any constraints } \\
\hline $\begin{array}{l}\text { Yes } \\
n=61 ; 40.1 \%\end{array}$ & 40 & 33.6 & 21 & 63.6 & \multirow{3}{*}{$\begin{array}{c}x^{2}=12.503 \\
p=0.002\end{array}$} \\
\hline $\begin{array}{l}\text { No } \\
n=73 ; 48.0 \%\end{array}$ & 66 & 55.5 & 7 & 21.2 & \\
\hline $\begin{array}{l}\text { Don't know } \\
\mathrm{n}=18 ; 11.9 \%\end{array}$ & 13 & 10.9 & 5 & 15.2 & \\
\hline \multicolumn{6}{|c|}{ The right to contract a same-sex marriage } \\
\hline $\begin{array}{l}\text { Yes } \\
n=39 ; 25.6 \%\end{array}$ & 23 & 19.3 & 16 & 48.5 & \multirow{3}{*}{$\begin{array}{c}x^{2}=12.932 \\
p=0.002\end{array}$} \\
\hline $\begin{array}{l}\text { No } \\
n=93 ; 61.2 \%\end{array}$ & 81 & 68.1 & 12 & 36.3 & \\
\hline $\begin{array}{l}\text { Don't know } \\
n=20 ; 13.2 \%\end{array}$ & 15 & 12.6 & 5 & 15.2 & \\
\hline \multicolumn{6}{|c|}{ The right to adopt children } \\
\hline $\begin{array}{l}\text { Yes } \\
n=16 ; 10.5 \%\end{array}$ & 9 & 7.6 & 7 & 21.2 & \multirow{3}{*}{$\begin{array}{c}x^{2}=18.387 \\
p<0.001\end{array}$} \\
\hline $\begin{array}{l}\text { No } \\
\mathrm{n}=122 ; 80.3 \%\end{array}$ & 104 & 87.4 & 18 & 54.5 & \\
\hline $\begin{array}{l}\text { Don't know } \\
n=14 ; 9.2 \%\end{array}$ & 6 & 5.0 & 8 & 24.2 & \\
\hline
\end{tabular}

that the place of residence of the respondents significantly differentiated the investigated feature $\left(\chi^{2}=9.238 ; p=0.025\right)$ in four of the respondents from rural areas, who more often than others had a positive attitude to homosexual employees.

\section{DISCUSSION}

Accepting the fact that sexual minorities exist is not always easy for heterosexual people. This statement is proved by the presented research, as well as by reports in the subject literature [4, 11-14]. In the studied group, every third student declared a negative attitude towards homosexuality, and more than a half were indifferent. On the basis of the collected material, it concept 'indifferent' should be explained and how it is meant in the research. It could be the usual reluctance to reveal a respondent's standpoint, or a lack of tolerance towards others. The explanation of this issue requires separate research.

In the last decades, there has been a slow increase in the social acceptance of people of homosexual orientation [15]. Increasingly often, heterosexual people not so much support, but do not oppose to public manifestations of the homosexual style of life [12-14]. In the presented study, almost half (46.7\%) of the students were unable (or did not want to) express their standpoint. On the other hand, approval of such manifestations was expressed by $27.6 \%$ of the respondents.
Table 2. The acceptance of the chosen social rights and the declared attitude to homosexuality

\begin{tabular}{|c|c|c|c|c|c|c|}
\hline \multirow{3}{*}{ Examined features } & \multicolumn{6}{|c|}{ Declared attitude to homosexuality } \\
\hline & \multicolumn{2}{|c|}{$\begin{array}{c}\text { Positive } \\
\mathrm{n}=23 ; 15.1 \%\end{array}$} & \multicolumn{2}{|c|}{$\begin{array}{c}\text { Negative } \\
n=47 ; 30.9 \%\end{array}$} & \multicolumn{2}{|c|}{$\begin{array}{c}\text { Indifferent } \\
\mathrm{n}=82 ; 54.0 \%\end{array}$} \\
\hline & $\mathrm{n}$ & $\%$ & $\mathrm{n}$ & $\%$ & $n$ & $\%$ \\
\hline \multicolumn{7}{|c|}{ The right to manifest one's own sexuality } \\
\hline $\begin{array}{l}\text { Yes } \\
n=42 ; 27.6 \%\end{array}$ & 16 & 69.6 & 2 & 4.3 & 24 & 29.3 \\
\hline $\begin{array}{l}\text { No } \\
n=39 ; 25.7 \%\end{array}$ & 1 & 4.4 & 27 & 57.4 & 11 & 13.4 \\
\hline $\begin{array}{l}\text { Don't know } \\
\mathrm{n}=71 ; 46.7 \%\end{array}$ & 6 & 26.0 & 18 & 38.3 & 47 & 57.3 \\
\hline Significance & \multicolumn{6}{|c|}{$x^{2}=56.16 ; p<0.0000001$} \\
\hline \multicolumn{7}{|c|}{ The right to perform a chosen profession without any constraints } \\
\hline $\begin{array}{l}\text { Yes } \\
n=61 ; 40.1 \%\end{array}$ & 19 & 82.6 & 8 & 17.0 & 34 & 41.5 \\
\hline $\begin{array}{l}\text { No } \\
\mathrm{n}=73 ; 48.0 \%\end{array}$ & 3 & 13.0 & 37 & 78.2 & 33 & 40.2 \\
\hline $\begin{array}{l}\text { Don't know } \\
\mathrm{n}=18 ; 11.9 \%\end{array}$ & 1 & 4.4 & 2 & 4.3 & 15 & 18.3 \\
\hline Significance & \multicolumn{6}{|c|}{$x^{2}=34.24 ; p=0.0000007$} \\
\hline \multicolumn{7}{|c|}{ The right to contract a same-sex marriage } \\
\hline $\begin{array}{l}\text { Yes } \\
n=39 ; 25.6 \%\end{array}$ & 16 & 69.6 & 0 & 0.0 & 23 & 28.0 \\
\hline $\begin{array}{l}\text { No } \\
\mathrm{n}=93 ; 61.2 \%\end{array}$ & 4 & 17.4 & 47 & 100.0 & 42 & 51.3 \\
\hline $\begin{array}{l}\text { Don't know } \\
n=20 ; 13.2 \%\end{array}$ & 3 & 13.0 & 0 & 0.0 & 17 & 20.7 \\
\hline Significance & \multicolumn{6}{|c|}{$x^{2}=53.75 ; p<0.0000001$} \\
\hline \multicolumn{7}{|c|}{ The right to adopt children } \\
\hline $\begin{array}{l}\text { Yes } \\
\mathrm{n}=16 ; 10.5 \%\end{array}$ & 10 & 43.5 & 0 & 0.0 & 6 & 7.3 \\
\hline $\begin{array}{l}\text { No } \\
n=122 ; 80.3 \%\end{array}$ & 8 & 34.8 & 46 & 97.9 & 68 & 82.9 \\
\hline $\begin{array}{l}\text { Don't know } \\
n=14 ; 9.2 \%\end{array}$ & 5 & 21.7 & 1 & 2.1 & 8 & 9.8 \\
\hline Significance & \multicolumn{6}{|c|}{$x^{2}=36.77 ; p=0.0000002$} \\
\hline
\end{tabular}

Homosexual men and women, and not only in Poland, demand from politicians the legalization of the right to contract a same-sex marriage and to adopt children $[12,15]$. This often encounters a strong social protest, as confirmed by th standpoints of the respondents: the right to contract same-sex marriages is denied by $61.2 \%$ and the right to adopt children is refused by $80.3 \%$. On the basis of the declared willingness to exclude homosexual men and women from some professions, it can be deduced that the anxiety and prejudices are quite strong. The specified professions specifically concern raising and educating children and working in health care. Similar observations have been made by other authors; however, their studies did not concern students $[2,4,6]$.

Some people fear the development of the rights of homosexuals as they believe that it would be at the expense of the rights of heterosexuals [4]. The reason for this attitude is unclear. It is known that homosexual men and women are anxious about the reaction of the social environment and often they try to hide their sexual orientation, especially in the workplace. 
The attitude of the students to all analyzed social rights significantly differentiated from the variables assumed in this study - the auto declaration of faith, as well as the declared attitude to homosexuality. This seems obvious because religion plays a crucial role in the life of believers. Among others, it provides specific norms and moral principles relevant to various spheres of human life in today's world [16]. This is probably why the search for correlation between the perception of homosexuality and religiousness can constitute an appealing subject for further research. The broad range of literature on the subject proves that point [16-22].

The social perception of homosexuality can be improved by broadly-understood education $[10,22]$. Peopl often do not realize the kind of problems homosexual men and women have to cope with every day, how difficult is for them to selfaccept in the environment which rejects them. Thus, while educating young medics, it is crucial not only to provide them with the knowledge of sexology, determined by the curriculum, but also with time for dialogue, discussion and consideration. This would enable them to better understand $r$ people with a different sexual orientation and be more tolerant [22]. It is worth remembering that 'tolerance' is a relative notion, which does not mean the acceptance of every situation. It is about the respect of freedom for other people, their thoughts, beliefs, and their assumed life style. Such an understanding of tolerance is particularly important in the medical professions as the broadly-understood health care must also take these issues into account.

\section{CONCLUSIONS}

1. The majority of medical university students declare an indifferent or negative attitude to homosexuality.

2. The majority of students oppose the legalization of rights for homosexual men and women, most often to the right to adopt children and contract same-sex marriages.

3. Acceptance of some rights for homosexual men and women is significantly differentiated by the students' attitude to homosexuality and their auto declaration of faith.

\section{REFERENCES}

1. Brodziak A, Kłopotowski T. Biologiczne i środowiskowe uwarunkowania orientacji seksualnej. Ann Acad Med Siles. 2013; 67(4): 256-267.

2. Talley AE, Bettencourt AB. Evaluations and aggression directed at a gay male target: The role of threat and antigay prejudice. J Appl Soc Psychol. 2008; 38(3): 647-683.
3. Vincent W, Parrott DJ, Peterson JL. Effects of Traditional Gender Role Norms and Religious Fundamentalism on Self-Identified Heterosexual Men's Attitudes, Anger, and Aggression Toward Gay Men and Lesbians. Psychol Men Masc. 2011; 12(4): 383-400.

4. Górska P, Mikołajczak M. Postawy wobec osób homoseksualnych. Wyd. Centrum Badań nad Uprzedzeniami. Warszawa 2014.

5. Juster RP, Smith NG, Ouellet É, et al. Sexual orientation and disclosure in relation to psychiatric symptoms, diurnal cortisol, and allostatic load. Psychosom Med. 2013; 75(2): 103-16.

6. Majka-Rostek D. Społeczne funkcjonowanie jednopłciowych związków partnerskich - homoseksualne pary w rodzinie, sąsiedztwie i pracy. [w:] Banaszak E, Czajkowski P. (red.), Moralne obrazy. Społeczne i socjologiczne (de)konstrukcje seksualności. Wyd. Uniwersytetu Wrocławskiego, Wrocław 2008.

7. Wacławik S. Homoseksualny oznacza chory? Stereotypowe powiązanie homo- i biseksualizmu z zaburzeniami psychicznymi na przykładzie wybranych filmów. Nowiny Lek. 2011; 80(5): 349-357.

8. Perdzyńska K. Sytuacja osób homoseksualnych w Polsce. Krytyczny przegląd. (w): Krzemiński I. (red.), Naznaczeni. Mniejszości seksualne w Polsce. Raport 2008. Wyd. Instytut Socjologii UW Warszawa, 2008: 13-65.

9. Kowalczyk R., Rodzinka M., Krzystanek M. Zdrowie osób LGBT. Przewodnik dla kadry medycznej. Kampania Przeciw Homofobii, Warszawa 2016: 15.

10. Stanisz A. Przystępny kurs statystyki w oparciu o program STATISTICA PL na przykładach z medycyny. Wyd. Stat Soft, Polska, Kraków, 2001.

11.Działa B. Społeczny odbiór osób homoseksualnych a edukacyjny potencjał filmu. Ogrody Nauk i Sztuk 2012; 2: 358-373.

12. Komunikat z badań. Stosunek do osób o orientacji homoseksualnej i związków partnerskich. CBOS, Warszawa, 2017.

13. Keleher A. Ran ES. Growing Support for Gay and Lesbian Equality since 1990. J Homosex. 2012; 59(9): 1307-1326.

14. Baunach DM. Decomposing Trends in Attitudes Toward Gay Marriage, 1988-2006. Soc Sci P. 2011; 92(2): 346-63.

15. Van den Akker H, van der Ploeg R, Scheepers P. Disapproval of homosexuality: Comparative research on individual and national determinants of disapproval of homosexuality in 20 European countries. Int J Public Opin Res. 2013; 25: 64-86.

16. Anderson R. Fetner T. Economic Inequality and Intolerance: Attitudes toward Homosexuality in 35 Democracies. Am J Pol Sci. 2008; 52(4): 942-958.

17. Kuptsevych A. The Influence Of Religiosity On The Attitudes Towards Homosexuality Among College Students. Minnesota State University - Makato 2014: 30-34.

18. Olson LR, Cadge W, Harrison JT. Religion and Public Opinion about Same-Sex Marriage. Soc Sci P. 2006; 87(2): 340-360.

19. Štulhofer A, Rimac I. Determinants of homonegativity in Europe. J Sex Res. 2009; 46: 24-32.

20. Whitehead AL, Baker JO. Homosexuality, Religion, and Science: Moral Authority and the Persistence of Negative Attitudes. Sociol Inq. 2012; 82(4): 487-509.

21. Sherkat DE, Powell-Williams M, Maddox G, de Vries KM. Religion, politics, and support for same-sex marriage in the United States, 19882008. Soc Sci Res 2010, 40(1): 167-180.

22. Hans JD, Kersey M, Kimberly C. Self-perceived origins of attitudes toward homosexuality. J Homosex. 2012; 59(1): 4-17. 